\title{
THE STUDY OF COMPARISON OF SUBLINGUAL VERSUS VAGINAL 25 MICROGRAM OF MISOPROSTOL IN INDUCTION OF LABOUR AT TERM
}

\author{
Zainab Z. Raja1 ${ }^{1}$ Jigar K. Thakkar², Megha S. Patel ${ }^{3}$, Jayun J. Joshi' ${ }^{4}$ Janki M. Pandya ${ }^{5}$, Hetal Patel
}

${ }_{1}^{1}$ Resident, Department of Obstetrics and Gynaecology, LG Hospital, Ahmedabad, Gujarat, India.

${ }^{2}$ Senior Resident, Department of Obstetrics and Gynaecology, LG Hospital, Ahmedabad, Gujarat, India.

3 Professor, Department of Obstetrics and Gynaecology, LG Hospital, Ahmedabad, Gujarat, India.

${ }_{4}^{4}$ Associate Professor, Department of Obstetrics and Gynaecology, LG Hospital, Ahmedabad, Gujarat, India.

${ }_{5}^{5}$ Assistant Professor, Department of Obstetrics and Gynaecology, LG Hospital, Ahmedabad, Gujarat, India.

${ }^{6}$ Resident, Department of Obstetrics and Gynaecology, LG Hospital, Ahmedabad, Gujarat, India.

ABSTRACT
BACKGROUND
Labour is the process by which the products of conception, when they have reached full term or nearing it, are expelled by the mother.
Induction of labour implies the artificial initiation of uterine activity to affect labour and delivery. The aim of successful induction is
to achieve vaginal delivery with a safe maternal and perinatal outcome and to eliminate any anticipated adverse outcome associated
with continuation of pregnancy. It should bring about adequate uterine activity sufficient for cervical changes and foetal descent to
occur without causing hyper stimulation or fatal compromise. Successful outcome of spontaneous labour is the result of well-
coordinated interplay between upper segments dominant and contracting, lower segment passive and dilating, Misoprostol is having
this property. The present study is undertaken to compare the efficacy, safety of sublingual vs. vaginal Misoprostol in induction of
labour at term pregnancy.

\section{MATERIALS AND METHODS}

In this randomized control trial, we had selected 100 antenatal women with term gestation admitted in antenatal ward and labour rooms. These cases were randomised into Group A and Group B. Group A included antenatal women receiving $25 \mu \mathrm{gms}$ of Misoprostol sublingually. Group B included antenatal women receiving $25 \mu \mathrm{gms}$ of Misoprostol vaginally in the posterior fornix. The dose is scheduled to be repeated once in every 4 hrs., if necessary, that is, if regular uterine contractions have not started within 4 hrs., of first dose.

\section{RESULTS}

Sublingual administration offers an excellent choice to women, particularly to those who were wishing to avoid vaginal administration. Sublingual Misoprostol is an effective alternative to vaginal Misoprostol in induction of labour. Sublingual route of administration was associated with higher incidence of hyperstimulation. Efficacy of both are almost similar in my study.

\section{CONCLUSIONS}

Induction delivery interval with sublingual misoprostol was less in comparison with vaginal misoprostol. In induction of labour with vaginal misoprostol, the rate of caesarean section was more in comparison with sublingual misoprostol. Furthermore, sublingual misoprostol possesses some advantages like convenience of administration.

\section{KEY WORDS}

Induction of Labour, Sublingual Misoprostol, Vaginal Misoprostol

HOW TO CITE THIS ARTICLE: Raja ZZ, Thakkar JK, Patel MS, et al. The study of comparison of sublingual versus vaginal 25 microgram of misoprostol in induction of labour at term. J. Evolution Med. Dent. Sci. 2019;8(12):937-940, D0I: $10.14260 /$ jemds/2019/208

\section{BACKGROUND}

Labour is the process by which the products of conception, when they have reached full term or nearing it, are expelled by the mother. World health organization (WHO) defines normal labour as "spontaneous in onset, low risk at the start of labour and remaining so throughout labour and delivery. The infant is born spontaneously in vertex presentation between 37 and 42 completed weeks of pregnancy.

'Financial or Other Competing Interest': None.

Submission 31-01-2019, Peer Review 10-03-2019,

Acceptance 16-03-2019, Published 25-03-2019.

Corresponding Author:

Jigar K. Thakkar,

D/502, Takshshila Resicom,

Near Idli Char Rasta,

Maninagar (e) Ahmedabad, Gujarat, India.

E-mail: jigarthakkar@19@gmail.com

DOI: $10.14260 /$ jemds $/ 2019 / 208$

\section{(c) $(1) \$$}

After birth, mother and infant are in good condition". A pregnant woman is considered low risk when no risk factors have been identified during antenatal or intrapartum period. Regular painful contractions of the uterus associated with effacement and dilation of cervix after 28 weeks and before 37 completed weeks of pregnancy constitute preterm labour. Induction of labour implies the artificial initiation of uterine activity to affect labour and delivery. Timely induction of labour plays such an important role in the antenatal management of so many problems that it merits consideration as a subject management of so many problems that it merits consideration as a subject in its own merit. The indications for induction have been steadily widened in recent year. The aim of successful induction is to achieve vaginal delivery with a safe maternal and perinatal outcome and to eliminate any anticipated adverse outcome associated with continuation of pregnancy. It should bring about adequate uterine activity 
sufficient for cervical changes and focal descent to occur without causing hyper stimulation or fetal compromise. The objective of pharmacological induction is to mimic the natural process as closely as possible. $(1,2,3,4,5)$ From the time immemorial PGE1 (Misoprostol tablet) and prostaglandins like PGE2 (Cerviprime gel) are being used for induction of labour. ${ }^{6}$ There is increasing evidence in the literature that PGE1, Misoprostol tablets plays an essential role in initiation and maintenance of parturition in humans. ${ }^{7}$ PGE1 analogue Misoprostol is stable at temperature it doesn't require storage in refrigerator of parenteral administration. ${ }^{8}$ It is an uterotonic agent with a wide range of clinical applications in obstetrics in induction of abortion, cervical ripening, and induction of labour at term. ${ }^{9}$ The use of Misoprostol for labour induction with a live fetus was 1st described in 1992 in the pioneering study by Margulies et al, successful induction of labour has been achieved by PGE1 administered orally and vaginally. ${ }^{10}$ Successful outcome of spontaneous labour is the result of well-coordinated interplay between upper segments dominant and contracting, lower segment passive and dilating, Misoprostol is having this property. The present study is undertaken to compare the efficacy, safely of sublingual vs. vaginal Misoprostol in induction of labour at term pregnancy.

\section{Procedure}

General examination as well as obstetric examination including vaginal examination is done to assess the condition and favourability of cervix. All preliminary baseline investigations like haemoglobin estimation Blood grouping and $\mathrm{Rh}$ typing, urine examination, and blood sugar estimation are done. Specific investigation like ultrasonography for fetal maturity, estimated weight of the baby, amniotic fluid index are done after recruitment to the study. The antenatal women are randomly assigned to receive Misoprostol tablets either sublingually or vaginally. In our study, out of 100 antenatal women, 50 women received $25 \mu \mathrm{gms}$ Misoprostol tablets sublingually and other 50 women received $25 \mu \mathrm{gms}$ Misoprostol tablets vaginally in the posterior fornix. The dose in scheduled to be repeated once in every $4 \mathrm{hrs}$., if necessary, that is if regular uterine contractions have not started within 4 hrs., of first dose.

Monitoring Foetal and maternal monitoring is done by clinical auscultation of foetal heart rate and uterine contractions by digital palpation. Progress of labour is assessed by abdominal examination which done once in every 30 minutes. Vaginal examination is done once in every 4 hours. Intrapartum events are recorded by maintaining a partogram. If the cervix is found unripe even after $4 \mathrm{hrs}$., $25 \mu \mathrm{gms}$ of Misoprostol tablets is repeated up to a maximum of doses. Oxytocin intravenous infusion is started in cases with infrequent contractions. The dose of Misoprostol is not repeated if foetal heart abnormalities occurred. If labour had not started within $48 \mathrm{Hrs}$, induction with Misoprostol tablets is abandoned and the cases is considered as failed induction, caesarean section is performed. Uterine Hypertonus is defined as single uterine contraction lasting for greater than 90 seconds. Tachysystole is defined as 6 or more uterine contractions in 10 minutes in two consecutive 10 minutes periods. Hyperstimulation syndrome defined as Tachysystole/hypertonus with non-reassuring foetal heart rare tracing. II and III stages of labour are managed as usual, following the standard protocol of the hospital. At birth, weight of the baby and APGAR score of the newborn at 1 minute and 5 minutes are recorded. Patients with LSCS, suture removal is done on 7 th postoperative day and patients are discharged on 8th day. Patients are explained to look for symptoms of sepsis like fever, pain abdomen, foul smelling lochia at the time of discharge. They are asked to report to the hospital if she observes any one of the symptoms.

\section{MATERIALS AND METHODS}

The Randomized control trial study is carried out in L.G HOSPITAL for the period of 1 year from 1 st June 2017 to 30 July 2018 recently. In the present study we had selected 100 antenatal women with term gestation admitted in antenatal ward and labour rooms, OPD of Department of Obstetrics and Gynaecology. All these cases were admitted for induction of labour of Misoprostol either by sublingual route or vaginal route. Sample size was taken for convenience.

This 100 Patients were randomized using computer generated random numbers and allocated into two groups into Group A and Group B. Group A included the antenatal women receiving $25 \mu \mathrm{gms}$ Misoprostol sublingually. Group B includes the antenatal women receiving $25 \mu \mathrm{gms}$ Misoprostol vaginally in the posterior fornix. The dose is scheduled to be repeated once in every $4 \mathrm{hrs}$ if necessary, that is, if regular uterine contractions have not started within 4 hrs of first dose.

\section{Inclusion Criteria}

1. Singleton Pregnancy.

2. Live Fetus.

3. Cephalic Presentation.

4. Bishop's Score $\leq 6$.

5. No detectable uterine contractions.

6. Completed 37 weeks of pregnancy.

\section{Statistical Analysis}

The Randomized control trial study is carried out in this study. Chi Square test was conducted respectively, SPSS version 17 was used for statistical analysis, and P Value Test has been applied.

P Value $>0.05$ No association.

P Value $<0.05$ Association.

\section{RESULTS}

The results of the study were recorded and analysed as follows,

\begin{tabular}{|c|c|c|}
\hline Indication & $\begin{array}{c}\text { Group A (Sublingual } \\
\text { Misoprostol) }\end{array}$ & $\begin{array}{c}\text { Group B (Vaginal } \\
\text { Misoprostol) }\end{array}$ \\
\hline Postdates & $33(66 \%)$ & $37(74 \%)$ \\
\hline PROM & $11(22 \%)$ & $6(12 \%)$ \\
\hline Mild PIH & $4(8 \%)$ & $5(10 \%)$ \\
\hline Severe PIH & $1(2 \%)$ & $2(4 \%)$ \\
\hline Oligo & $1(2 \%)$ & - \\
\hline Total & 50 & 50 \\
\hline Table 1. Distribution of Cases According to Indication for \\
Induction Indication \\
\hline \multicolumn{3}{|c|}{ p Value > 0.05 } \\
\hline
\end{tabular}




\begin{tabular}{|c|c|c|}
\hline Bishop Score & $\begin{array}{c}\text { Group A (Sublingual } \\
\text { Misoprostol) }\end{array}$ & $\begin{array}{c}\text { Group B (Vaginal } \\
\text { Misoprostol) }\end{array}$ \\
\hline $0-3$ & $21(42 \%)$ & $18(36 \%)$ \\
\hline $4-6$ & $29(58 \%)$ & $32(64 \%)$ \\
\hline Total & 50 & 50 \\
\hline \multicolumn{3}{|c|}{ Table 2. Distribution of Cases in Relation to Bishop's Score } \\
Bishop Score \\
\hline \multicolumn{3}{|c|}{ p Value >0.05 } \\
\hline
\end{tabular}

\begin{tabular}{|c|c|c|}
\hline $\begin{array}{l}\text { Total Dose of } \\
\text { Misoprostol }\end{array}$ & $\begin{array}{l}\text { Group A (Sublingual } \\
\text { Misoprostol) }\end{array}$ & $\begin{array}{l}\text { Group B (Vaginal } \\
\text { Misoprostol) }\end{array}$ \\
\hline 25 & $21(42 \%)$ & $15(30 \%)$ \\
\hline 50 & $16(32 \%)$ & $19(38 \%)$ \\
\hline 75 & $9(18 \%)$ & $11(22 \%)$ \\
\hline 100 & $3(4 \%)$ & $4(8 \%)$ \\
\hline 125 & $1(2 \%)$ & $1(2 \%)$ \\
\hline Total & 50 & 50 \\
\hline \multicolumn{3}{|c|}{$\begin{array}{c}\text { Table 3. Distribution of Cases According to Total Dosage } \\
\text { of Misoprostol }(\mu g)\end{array}$} \\
\hline \multicolumn{3}{|c|}{ p Value $>0.05$} \\
\hline
\end{tabular}

\begin{tabular}{|c|c|c|}
\hline Mode of Delivery & Group A & Group B \\
\hline Vaginal & $36(72 \%)$ & $32(64 \%)$ \\
\hline Caesarean & $14(28 \%$ & $18(36 \%)$ \\
\hline Total & 50 & 50 \\
\hline Table 4. Distribution of Cases in Relation to Mode of \\
Delivery \\
\hline \multicolumn{3}{|c|}{ p Value $>0.05$} \\
\hline
\end{tabular}

\begin{tabular}{|c|c|c|}
\hline $\begin{array}{c}\text { Indication of } \\
\text { Caesarean }\end{array}$ & $\begin{array}{c}\text { Group A (Sublingual } \\
\text { Misoprostol) }\end{array}$ & $\begin{array}{c}\text { Group B (Vaginal } \\
\text { Misoprostol) }\end{array}$ \\
\hline Fetal Distress & $10(72 \%)$ & $8(44 \%)$ \\
\hline $\begin{array}{c}\text { Non-Progress of } \\
\text { Labour }\end{array}$ & $4(28 \%)$ & $10(56 \%)$ \\
\hline \multicolumn{3}{|c|}{ of Caesarean Section } \\
\hline Table 5. Distribution of Cases in Relation to Indications \\
\hline \multicolumn{2}{|c|}{ p Value >0.05 } \\
\hline
\end{tabular}

\begin{tabular}{|c|c|c|}
\hline Complication & $\begin{array}{c}\text { Group A (Sublingual } \\
\text { Misoprostol) }\end{array}$ & $\begin{array}{c}\text { Group B (Vaginal } \\
\text { Misoprostol) }\end{array}$ \\
\hline Atonic & $1(2 \%)$ & $2(4 \%)$ \\
\hline Traumatic & $2(4 \%)$ & $2(4 \%)$ \\
\hline Total & 3 & 4 \\
\hline Table 6. Complications of Third Stage of Labour \\
\hline \multicolumn{3}{|c|}{ p Value $>0.05$} \\
\hline
\end{tabular}

\begin{tabular}{|c|c|c|}
\hline & $\begin{array}{c}\text { Group A (Sublingual } \\
\text { Misoprostol) }\end{array}$ & $\begin{array}{c}\text { Group B (Vaginal } \\
\text { Misoprostol) }\end{array}$ \\
\hline$<12$ Hour & $34(68 \%)$ & $31(62 \%)$ \\
\hline $12-24$ Hour & $15(30 \%)$ & $18(36 \%)$ \\
\hline$>24$ Hour & $1(2 \%)$ & $1(2 \%)$ \\
\hline Table 7. Distribution of Cases in Relation to Induction \\
Delivery Interval \\
\hline \multicolumn{3}{|c|}{ p Value $>0.05$} \\
\hline
\end{tabular}

\begin{tabular}{|c|c|c|}
\hline Gravida & $\begin{array}{c}\text { Group A (Sublingual } \\
\text { Misoprostol) }\end{array}$ & $\begin{array}{c}\text { Group B (Vaginal } \\
\text { Misoprostol) }\end{array}$ \\
\hline Primigravida & 11 & 12 \\
\hline Second & 9 & 10 \\
\hline Third & 8 & 9 \\
\hline Fourth & 9 & 8 \\
\hline \multicolumn{3}{|c|}{ Table 8. Relationship Between Gravida and Induction } \\
Delivery Interval \\
\hline \multicolumn{3}{|c|}{ p Value >0.05 } \\
\hline
\end{tabular}

\section{DISCUSSION}

In table 2 sublingual misoprostol is more effective than vaginal misoprostol when bishop score was between 0-3. In table 4 caesarean section was less with sublingual misoprostol than vaginal misoprostol. In table 5, when induction of labour done with vaginal route the rate of caesarean section was more and the indication of caesarean section was non progression of labour. In table 6 , the complication of 3 rd stage of labour i.e., atonic and traumatic post-partum haemorrhage was more vaginal misoprostol. In table 7 , induction delivery interval with sublingual misoprostol was less in comparison with vaginal misoprostol. In table 8 , induction delivery interval in primigravida and second gravida with sublingual misoprostol was less in comparison with vaginal misoprostol, but in multigravida induction delivery interval was same with both.

\section{CONCLUSIONS}

1. The average induction delivery interval is less in sublingual misoprostol as compared to vaginal misoprostol.

2. Sublingual administration offers an excellent choice to women, particularly to those who were wishing to avoid vaginal administration.

3. Sublingual Misoprostol is an effective alternative to vaginal Misoprostol in induction of labour

4. Sublingual route of administration was associated with higher incidence of Hyperstimulation.

5. Efficacy of both are almost similar in my study.

\section{REFERENCES}

[1] Ratnam SS, Kumaran ABR. Obstetrics and Gynecology for postgraduates. Vol. 1. 2004: p. 96-108.

[2] Mudaliar AL. Mudaliar and Menon's Clinical Obstetrics. $10^{\text {th }}$ edn. Orient Blackswan 2005.

[3] Misra R. Induction of labour. Chap - 25. Ian Donald's Practical obstetric problems. 7th edn. New Delhi: Wolters Kluwer India Pvt Ltd., 2014: p. 488.

[4] Cunningham GF, Leveno KJ, Bloom SL, et al. William Obstetrics. Induction and augmentation of labour. 24th edn. McGraw-Hill Publication 2012: p. 523-35.

[5] Kumaran SA, Penna LK. Prelabor ROM. The management of labour. $2^{\text {nd }}$ edn. Orient Longman 2005: p. 306-18.

[6] Feitosa FE, Sampaio ZS, Alencar CA Jr, et al. Sublingual vs vaginal misoprost for induction of labor. Int J Gynaecol Obstet 2006;94(2):91-5.

[7] Bartusevicius A, Barcaite E, Krikstolaitis R, et al. Sublingual compared with vaginal Misoprostol for labour induction at term: a randomized controlled trial. BJOG 2006;113(12):1431-7. 
[8] Sheela CN, Mhaskar A, George S. Comparison of vaginal misoprostol and oral misoprostol with intra cervical dinoprostone gel for labour induction at term. Journal of Obstetrics and Gynaecology of India 2007;5(4):32730.

[9] De Moraes FOB, De Albuquerque RM, Pacheco AJC, et al. Sublingual versus vaginal Misoprostol for induction of term pregnancies. Rev Bras Gynecol Obstet 2005;27(1):24-31.
[10] Khatri A, Sharma J, Amatya A. Oral: vaginal misoprostol: which route for induction of term labor. Nepal Journal of Obstetrics and Gynaecology 2007;2(1):23-28. 